\title{
A Tale of Two Cities and the Cold War
}

\author{
ROBERT GIDDINGS
}

There was probably never a book by a great humorist, and an artist so prolific in the conception of character, with so little humour and so few rememberable figures. Its merits lie elsewhere. (John Forster, The Life of Charles Dickens (1872))

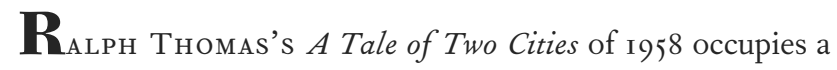
secure if modest place among that bunch of I950s British releases based on novels by Dickens, including Brian Desmond Hurst's Scrooge (I95I) and Noel Langley's The Pickwick Papers (1952). ${ }^{\mathrm{I}}$ When all the arguments about successfully filming Dickens are considered it must be conceded that his fiction offers significant qualities that appeal to film-makers: strong and contrasting characters, fascinating plots and frequent confrontations and collisions of personality. In unsuspected ways, Ralph Thomas's film is indeed one of the best film versions of a Dickens novel and part of this rests upon the fact that, as Dickens's novels go, $A$ Tale of Two Cities is unusual. Dickens elaborately works up material in this novel which must have been marinating in his imagination. Two themes stand out: the dual personality, the doppelgänger or alter ego; and mob behaviour when public order collapses. Several strands come together. Dickens had voluminously researched the Gordon Riots which were, up to then, the worst public riots in British history. Charles Mackay's Popular Delusions and the Madness of Crowds (1845)

\footnotetext{
I am Professor Emeritus in the School of Media Arts, Bournemouth University. My schooling was interrupted by polio, but I was very well educated by wireless, cinema and second-hand books. As an undergraduate in Bristol in the I950s I spent more time in film societies and flea-pits than in class. This cultural irresponsibility has continued and been complicated by TV and video. I have written for New Society, Tribune, The Listener and New Statesman and Society on film and media, and published The Changing World of Charles Dickens (Vision Press, 1984); with Chris Wensley and Keith Selby, Screening the Novel (Palgrave, 1992); The War Poets (Bloomsbury, 1998); and with Keith Selby, The Classic Serial on Television and Radio (Palgrave, 200I). I am a devout and practising Dickensian: my Student Guide to Charles Dickens was published in 2002 by Greenwich Exchange. Robert Giddings
} 
was in his library at Gad's Hill. Dickens was a young parliamentary reporter when one of the most dreadful political riots took place during Reform agitation in Bristol in I83. Reading Thomas Carlyle's History of the French Revolution (1837) kindled his interest in mob violence. He read it constantly and carried it in his pocket. According to John Forster, his first biographer, Dickens claimed to have read it five hundred times. He heard Carlyle lecture in 1840 and was deeply impressed. ${ }^{2}$ The violence implicit in Chartist agitation caused much anxiety. As the economy deteriorated, the Chartist challenge became more pressing and public order became an issue, Dickens found the manifestation of the mob an ever more fascinating subject. The Anti-Corn Law League was formed in 1838 ; in 1839 there were Chartist riots in Birmingham during July where force was used against the imported Metropolitan Police and again at Newport in November. Britain had survived the Chartist threat. (Dickens himself had served as a 'Special Constable' (a volunteer policeman) during the height of Chartist agitation in I848.) The British now read about revolutions in Paris, Berlin, Budapest, Vienna. Dickens had been an eye-witness of the Genevese revolution in I846. In January I 858 there was an assassination attempt on Napoleon III in which ten people were killed and I 50 injured. As France assisted the attempts to free Italy from Austrian domination, revolutions occurred in Tuscany, Modena, Parma, Bologna, Ferrara and Ravenna. Abroad was a dangerous place to British eyes.

These events were the stuff of headlines during the publication of $A$ Tale of Two Cities. It posed an ideal: a quiet industrious life in England in contrast to the violence, injustice and insecurity of France. This was shadowed forth in the wrapper to the monthly serial parts of $A$ Tale of Two Cities. Hablot Browne's engraving shows prosperous, mercantile London at the top (ships, merchandise, peaceful panoramic cityscape) and French revolutionary violence at the bottom of the page (guillotine, tumbril, agitators, crowds, revolutionary caps); these were the very different 'Two Cities'.

A Tale of Two Cities certainly has its weaknesses, including the notorious Dickensian melodrama, sentimentality and theatricality of dialogue. It offers few well-drawn locations or striking characters. Apart from the obvious fear of public violence, it has little to say in terms of social comment. The tedious nature of the plot is further rendered unattractive by the fact that it is very difficult to identify with any of the leading characters. Its narrative is simple. Charles is a good-looking young French aristocrat living in England, from a family held in particular loathing for its brutal treatment of social inferiors before the Revolution. His family in Paris is attacked and their tax and rent collector, Gabelle, writes to England begging his help. 
Charles returns to France, is arrested and sentenced to death. His life is saved by Sydney Carton, a drunken and dissolute young lawyer, whom physically he resembles. Charles and Sydney are both in love with Lucie Manette, daughter of a French aristocrat long incarcerated in the Bastille. Carton smuggles Charles out of prison and dies in his stead at the guillotine. $\mathrm{He}$ goes to his death with the words, 'It is a far, far better thing that I do, than I have ever done; it is a far, far better rest that I go to than I have ever known.'

The novel leaves a major impression of an elemental sweep of mob violence. Despite the passages inserted about the abuse of power by the aristocracy to justify the rising of the French people, Dickens's revolution is totally devoid of any political idealism. Sydney Carton martyrs himself to save the skin of an aristocrat. The most memorable of the revolutionaries is Madame Defarge, whose zeal is motivated more by vengeance than the wish to make the world a better place. By the time we reach the sections where Monsieur Defarge and his followers at the wine shop are plotting to rebel, adding names to the list of people to be revenged upon, it is all pure Tappertit and personal vendetta. It is only in the crowd scenes that $A$ Tale of Two Cities really comes to life.

The reception of Charles Dickens's A Tale of Two Cities was mixed. It was not critically acclaimed. It was serialised weekly in All the Year Round, but Dickens came up with what he called the 'rather original and bold idea' to publish at the end of each month a shilling monthly part in a green cover with two illustrations. ${ }^{3}$ Sales were good. By March 1859 monthly instalments totalled 35,000. Nevertheless the general feeling seems to have been that while Hard Times and Little Dorrit showed signs of Dickens's magic beginning to fade, A Tale of Two Cities was frankly dull to the readership which had greedily lapped up David Copperfield and the earlier novels. But the novel did subsequently enjoy a vigorous life of its own as play, film, radio, television and opera, an enduring vitality shared by very few novels, possibly only rivalled by $W$ ar and Peace. ${ }^{4}$

A Tale of Two Cities was filmed several times, in silent and talkie versions, and frequently serialised on BBC radio and television. Arthur Benjamin's opera $A$ Tale of Two Cities was premièred in 1950 and broadcast by BBC television in $1958.5^{\circ} \mathrm{CBS}$ produced a TV movie version in 1980 in which Chris Sarandon played both roles of Darnay and Carton. Variety praised the 'impressive costumes and plenty of candles'. Indeed, interest in the novel has to a considerable extent been maintained by the media which find melodrama the very stuff of entertainment.

We are used to radio, film and TV dramatisations of the classics, the media's continuation of literature by other means. The Victorians were well 
used to stage versions of novels of the day, not only East Lynne, Lily of Killarney and Lady Audley's Secret but more serious books as well. Dickens was sometimes a willing collaborator. A Tale of Two Cities had a long theatrical life which extended well into the twentieth century, and served to turn Carton into the star of the show. The influence of $A$ Tale of Two Cities on film-makers was clear and is very marked in D.W. Griffith's Orphans of the Storm of 1921. The crowd scenes are still impressive. The novel was filmed again in 1926 with Maurice Costello and John Martin-Harvey as The Only Way. A famous version with Ronald Colman came out in I935. Filmmakers may endeavour to be faithful in rendering past classics, but dramatisations of classic novels always carry the fingerprints of their own time. Dickens viewed the French Revolution as an arriviste of mid-Victorian genteel society, trying to come to terms with the impact of a major political upheaval not so very long before his own time. He had the heart of a socialist, but some instincts of a conservative. He sympathised with the plight of the poor and the dispossessed, but feared what would happen if the masses got together to right social wrongs. This accounts for the suspicion of trade unions in Hard Times and the swirling mobs in Barnaby Rudge and $A$ Tale of Two Cities. When he writes of late eighteenth-century French history there is Chartist agitation at home at the back of his mind. Similarly, Ralph Thomas's film of $A$ Tale of Two Cities was released in the tense atmosphere of the Cold War. And it shows.

Ten years previously the United Kingdom, France, Belgium, Luxembourg and the Netherlands signed the Brussels Treaty, allying themselves against armed attack in Europe. Three days after the Treaty was signed, the USSR delegates walked out of the Allied Control Commission for Germany. The Berlin air lift began on 24 June 1948. As the free world and the eastern-bloc countries stockpiled arms and suspiciously faced each other, the Rosenbergs were executed for spying for the Reds, the Korean War broke out, Alger Hiss was found guilty of perjury in concealing his Communist Party membership, the atom spy Klaus Fuchs was exposed, Senator Joseph McCarthy investigated the State Department, and Burgess and MacLean fled to the USSR. The atomic bomb overshadowed the decade. There were claims and counter-claims between the powers about espionage. The Hungarian crisis dominated the news in 1956 . Anxiety seeped into the way the age explored its values and expressed itself. The division of our world into two opposing power blocs produced a pressure for social and political conformity. Conformism and 'belongingness' replaced Protestant individualism, the theme of Herman Wouk's novel The Caine Mutiny (I95I), a key work of the decade. In it the crew of a US minesweeper are led by Steve 
Maryk, the executive officer, to mutiny against the paranoid and incompetent Captain Queeg. In the subsequent court martial Maryk is acquitted and Queeg exonerated because the survival of 'corporate management' is judged as more important than satisfaction of individual conscience. This theme was very strongly represented in Wouk's stage play, The Caine Mutiny Court-Martial (1954), on which the film version of the same year, with Bogart as Queeg, was based.

The massive nation state of Soviet Russia was believed to pose an active threat to the western world. Russia had, of course, gone down the road of revolution whereas the free world had taken the more careful democratic route. Its cautious consensual progress was consolidated in the post-war settlement, its modest optimism maintaining a fragile balance which typified the British 'tone' of the 1950s. In 1955 the American Edward Shils observed Britain's security curiously in Encounter:

Who criticizes Britain now in any fundamental sense, except for a few Communists and a few Bevanite irreconcilables? There are complaints here and there and on many specific issues, but - in the main - scarcely anyone in Britain seems any longer to feel that there is anything fundamentally wrong. On the contrary, Great Britain on the whole, and especially in comparison with other countries, seems to the British intellectual of the mid-1950s to be all right and even much more than that.

What were the tastes and values which had so reconciled the readership of Encounter at this period (in which Shils was writing) to the 'Englishness of English life'? Shils may not have got it right, but his perception was that it was 'continental holidays, the connoisseurship of wine and food, the knowledge of wild flowers and birds, acquaintance with the writings of Jane Austen, a knowing indulgence for the worthies of the English past, an appreciation of the more leisurely epochs, doing one's job dutifully and reliably, the cultivation of personal relations - these are the elements in the ethos of the emerging British intellectual class'. So it seemed, and the seemings of nations are significant. When the English looked abroad, or around them on a 'continental holiday', they saw little national concord. ${ }^{6}$ France seemed unable to achieve stable government and had serious trouble in Algeria. Germany was divided. The European nations under communism were kept in place by repression. Across the Atlantic there was the wealthy but materialistic United States, a nation who had bought 'civilisation' at the price of 'culture'. The British watched wryly and were aware of tears in the fabric of world stability. The Cold War was therefore the backdrop for many anxious mystery stories and thrillers. Ian Fleming's novels (the novels rather than the later jovially fatuous features films) dominated popular fiction lists in the 
I950s: Casino Royale (1953), Moonraker (1955), Diamonds Are Forever (1956), Doctor No (1958), Goldfinger (1959). There were the Graham Greene fictions of espionage: The Quiet American (1955) and Our Man in Havana (1958). The Cold War as subject for film was initiated by the film which Arthur Marwick calls 'the film of Post-War Europe', that is, Carol Reed's and Greene's The Third Man (1949). Cinema audiences consumed such treatments of the Cold War as The Big Lift (1950), The Red Danube (1950), I Was a Communist for the FBI (1951), Diplomatic Courier (1952) and The Man Between (1953).

Ralph Thomas said that he was mainly interested in making films which expressed contemporary sentiments and ideas whatever their subject. 'Generally speaking, I look for a story that is a reflection of the modes and manners of the times. ${ }^{7}$ To see $A$ Tale of Two Cities in this context is to recognise British calm, an inner stability in a troubled world. Thomas revelled in 'us versus them' structures. In 1955 he had directed Above Us the Waves, a naval war picture starring John Mills which bodied forth the struggle between a midget submarine and the might of Nazi sea power. In 1958 he directed an adaptation of Richard Mason's romantic wartime novel The Wind Cannot Read, with Dirk Bogarde as a naive British officer who falls in love with a young Japanese interpreter with terminal brain disease. ${ }^{8}$ The doomed romance is enacted in a threatening and exotic (and confusing) Raj setting. It has one extraordinary sequence, usually cut for transmission on British television, in which Bogarde is captured by the Japanese, who are played as robotic martinets. They command Bogarde's loyal Sikh fellow officer to spit on him. Under duress, he does so, and then makes a dash for it. The Japanese officer shoots him in the back.

It is Dirk Bogarde who stars as Sydney Carton in Ralph Thomas's $A$ Tale of Two Cities. He remembered it as a well-dressed failure.

We had a most impressive cast of (mainly) theatre actors; enormous care was lavished on the authenticity of the sets and costumes; we went all the way to Bourges in France and shot the film there. But even though it was a faithful 'reproduction' of Dickens, even though we spoke his words and delivered his rather preposterous plot perfectly to the screen, the film failed. My contention is that (a) they wanted Ronald Colman, and (b) we cut costs and made it in black and white ... As a 'classic' adaptation, it could not be faulted, but it did not transfer to the screen of the late fifties. It was not of its time.?

Nevertheless, $A$ Tale of Two Cities has the fingerprints of the I950s all over it and the film sits comfortably in its historical moment. The film's main action is placed in the context of threatening revolutionary change, but its narrative style - vigorously eschewing the characteristically Dickensian grotesque and opting for rather humdrum cinematic historical realism - is timidly 
conformist. This manner is established at the outset in the opening credits. Thomas deploys old prints to give a straightforward sense of the past. British stability, good common sense and, at bottom, guts and courage, are represented in the sturdy person of Cecil Parker as Jarvis Lorry, manager of Tellson's bank. Parker was a familiar figure to cinema-goers: The Man in the White Suit (1951), I Believe In You (1952), Isn't Life Wonderful and Father Brown (both 1954), The Constant Husband and The Ladykillers (both 1955). His physique, plummy voice and controlled fussiness enabled him to play both warm-hearted characters and management types. As Jarvis Lorry he projects the decent paternalism required to safeguard such vulnerable fugitives from political chaos in France as Lucy Manette and her father. He is counterbalanced across the Channel by Christopher Lee as the evil aristocrat who indifferently runs his horses over peasant lads and or rogers the chateau servants. Memories are invoked of his sinister presence in Moby Dick (1956), Ill Met by Moonlight (1956), The Traitor (1957) and above all Lee's Frankenstein's monster, which he first played on screen in 1956 . His definitive impersonation of Dracula was also on release at the same time as $A$ Tale of Two Cities. With such dark tones, no screen performer could so credibly project casual menace. The fragile Lucy Manette was radiantly presented by Dorothy Tutin in a performance which drew on her experience as Gwendolen in The Importance of Being Earnest (1952) and Polly in Peter Brook's The Beggar's Opera (1952), as well as stage roles such as Rose in Graham Greene's The Living Room (1953), Sally in John Van Druten's I am a Camera (1954), St Joan in Jean Anouilh's The Lark and Hedvig in Ibsen's The Wild Duck (both in 1955). When A Tale of Two Cities was in the cinemas, she was a brilliant success in three Shakespearean leads, Viola, Ophelia and Juliet. Tutin was well able to convey both vulnerable innocence and sexual magnetism. On the big screen 1950 os audiences were delighted to see her with the eyes seen by Bogarde's Sydney Carton who sacrificed himself for her and them. The role of Carton's double, Charles Darnay, was played by Paul Guers, who only vaguely resembled Bogarde. The cinematic trick of having both parts played by the same actor was resisted. The theme of the doppelgänger which so fascinated the gothic romantics (Hoffmann, Heine, Poe) was given only subdued treatment by Dickens and Thomas, who were not to be drawn into phantasmagoric excess. Donald Pleasance as the spy Barsad represented the materialist, non-idealist agent with neither relish for nor loyalty to the profession of espionage. 'I admit that I am a spy, and that it is considered a discreditable station - though it must be filled by somebody.' He offers his services in typically I950s style by telling Bogarde and his companions, 'I could be a very useful comrade.' 
The tragic love entanglements of the plot are played out against a very cursorily sketched French Revolution which in this film appears to have been ignited by little more than a couple of broken barrels of wine and some careless driving on the part of a single aristocrat. Just as Dickens's readers could enjoy the adventures in safety while the raging battle between good and bad took place safely on the other side of the Channel, so the ig5os could relish the contest between well-spoken Englishmen and treacherous East Europeans in the Cold War. Britain in the I950s may have had its drab side, but it afforded a safe view of European intensities.

\section{Notes}

I My epigraph is taken from Book IX, Chapter 2 of Forster's Life. For film adaptations of Dickens, see David Parossien, 'Dickens and the Cinema', Dickens Studies Annual 7 (Southern Illinois Press, 1978) and Robert Giddings, 'Great Misrepresentations: Dickens and Film', Critical Survey (I99I), Pp. 305-I2.

2 John Forster, The Life of Charles Dickens, 1872, Book IX, Chapter 2 (Chapman and Hall, Fireside edition), p. 796.

3 William Oddie, Dickens and Carlyle: The Question of Influence (Century Press, I972), p. 6I.

4 War and Peace was filmed by Vitagraph in I9II. It is frequently claimed that D.W Griffith's French Revolutionary film Orphans of the Storm (I92I) borrows from the novel: see Kevin Brownlow, The Parade's Gone By (Secker \& Warburg, I968) pp. I4-I6, 84-85. War and Peace was notably filmed by King Vidor (1956) and Serge Bondarchuk (1964). It was adapted for the stage, and a television version by R.D. MacDonald, transmitted by Granada in 1963, won an Emmy Award. It was the subject of an opera by Prokofiev, first performed 1946 (revised and extended 1955). Jack Pulman's magisterial serial dramatisation for television was transmitted by $\mathrm{BBC}_{2}$ in $\mathrm{I}_{972}$. The novel has been well served by $\mathrm{BBC}$ radio as a classic serial; the last version was broadcast in 1997 .

5 The television production, by Rudolph Cartier, utilised three studios, a cast of 120 and the Royal Philharmonic Orchestra conducted by Leon Lovett. It was the most spectacular musical production undertaken by British television that decade.

6 Edward Shils is quoted by Robert Hewison in In Anger: Culture and the Cold War, 19452960 (Methuen, I98I), p. 72. Shils was a sociologist who taught at the London School of Economics and at Manchester University.

7 Ralph Thomas, quoted by Ronald Bergan in obituary of Thomas (I915-200I), Guardian (20 March 200I).

8 The Wind Cannot Read was to have been directed by David Lean, but the producer, Korda, was not satisfied with Lean's approach to the subject. It was sold to Rank and landed on Ralph Thomas's desk.

9 Dirk Bogarde in 'Books Are Better', Literary Review (July 1994), reprinted in For The Time Being (Penguin, 1998). 